Van Dam, A.A. et al. (2014). A synthesis of past, current and future research for protection and management of papyrus (Cyperus papyrus L.) wetlands in Africa.

Wetlands, Ecology and Management, 22: $99-114$

http://dx.doi.org/10.1007/s11273-013-9335-1

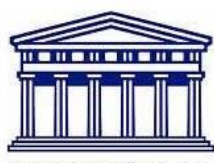

UNIVERSITY of the WESTERN CAPE

\title{
A synthesis of past, current and future research for protection and management of papyrus (Cyperus papyrus L.) wetlands in Africa
}

\author{
A. A. van Dam, J. Kipkemboi, D. Mazvimavi and K. Irvine
}

\begin{abstract}
Papyrus wetlands (dominated by the giant sedge Cyperus papyrus L.) occur throughout eastern, central and southern Africa and are important for biodiversity, for water quality and quantity regulation and for the livelihoods of millions of people. To draw attention to the importance of papyrus wetlands, a special session entitled "The ecology of livelihoods in papyrus wetlands" was organized at the 9th INTECOL Wetlands Conference in Orlando, Florida in June 2012. Papers from the session, combined with additional contributions, were collected in a special issue of Wetlands Ecology and Management. The current paper reviews ecological and hydrological characteristics of papyrus wetlands, summarizes their ecosystem services and sustainable use, provides an overview of papyrus research to date, and looks at policy development for papyrus wetlands. Based on this review, the paper provides a synthesis of research and policy priorities for papyrus wetlands and introduces the contributions in the special issue. Main conclusions are that (1) there is a need for better estimates of the area covered by papyrus wetlands. Limited evidence suggests that the loss of papyrus wetlands is rapid in some areas; (2) there is a need for a better understanding and modelling of the regulating services of papyrus wetlands to support trade-off analysis and improve economic valuation; (3) research on papyrus wetlands should include assessment of all ecosystem services (provisioning, regulating, habitat, cultural) so that trade-offs can be determined as the basis for sustainable management strategies ('wise use'); (4) more research on the governance, institutional and socio-economic aspects of papyrus wet- lands is needed to assist African governments in dealing with the challenges of conserving wetlands in the face of growing food security needs and climate change. The papers in the special issue address a number of these issues.
\end{abstract}

\section{Introduction}

Cyperus papyrus L. (1753), commonly referred to as papyrus, is a perennial herbaceous sedge native to Africa where it occurs as extensive vegetation along riverine, floodplain and fringing wetlands. It occurs in southern, central and eastern Africa and the Nile valley predominantly in the riverine and lacustrine marshes between latitudes $17 \mathrm{~N}$ and $29 \mathrm{~S}$ and between sea level and an altitude of about 2,300 $\mathrm{m}$ (Thompson 1976; Jones and Muthuri 1985; McClanahan and Young 1996). Besides representing a major habitat for birds, fish and wildlife, papyrus swamps also support the livelihoods of millions of rural people in sub- 
Saharan Africa through their ecosystem functions and services, by providing e.g. water, food and building materials to local communities and as the basis for a rich cultural tradition. Moreover, they deliver important ecosystem services on a larger scale through their biogeochemical processes (e.g. their impact on nitrogen flows) and impact on the hydrological cycle and climate (Kiwango and Wolanski 2008; van Dam et al. 2011).

The biodiversity and ecosystem services of Africa's freshwater ecosystems, including wetlands, are increasingly degraded (Darwall et al. 2011). The exact areal extent of papyrus wetlands in Africa is not known exactly, but the pressure from agricultural and urban/industrial development on papyrus has definitely been increasing. African nations need to increase food production and adapt to the impacts of climate change. Increasingly wetlands are the victim of this through conversion to cropland or through other economic activities (Rebelo et al. 2010; Hachigonta et al. 2013; Wood et al. 2013). Local studies in Kenya (e.g. Owino and Ryan 2007) and Uganda (Namaalwa et al. 2013) demonstrate irreversible conversion of papyrus wetlands into agricultural land.

The recognition of the importance of wetlands is not new. Globally, 168 parties (member states) have joined the Ramsar Convention on Wetlands to protect and conserve wetlands and their ecosystem services (www. ramsar.org, November 2013). Since its signing in 1971, 47 African countries have joined the Convention, and six more are expected to join in the near future (Ouedraogo 2013). African countries have also made progress in developing national strategies for wetland conservation and management, but the process is slow. Only 12 countries have a national policy, and 14 have completed an inventory (Gardner et al. 2009; Ouedraogo 2013). Integrating wetland policy with other sectors (e.g. water resources management, agriculture) and incorporating transboundary aspects of wetland conservation and management remain particularly challenging. Africa's progress in practical implemen- tation of the Convention is further constrained by lack of human capacity, budget and infrastructure (Gevers and Koopmanschap 2012; Ostrovskaya et al. 2013).

Knowledge of wetland ecosystems is a fundamental prerequisite for effective policies and management. One of the earliest scientific descriptions of papyrus was made by the 19th century Rev. Henry Baker Tristram (Tristram 1866) from his trip to the Lake of Galilee and Lake Huleh in the middle East. In his later books, he describes the papyrus plant and its use (fuel, mats, house construction) and also reports papyrus as extinct from Egypt and Africa, "excepting in marshes of the White Nile in Nubia, $7^{\circ}$ north latitude" (Tristram 1883). Although regular publications on papyrus have been produced since the 1970s, information on the functions of papyrus wetlands and how these can be conserved under increasing human pressure remain limited.

Drawing attention to the importance of papyrus wetlands was the aim of a special session at the 9th INTECOL Wetlands Conference in Orlando, Florida in June 2012. This special issue of Wetlands Ecology and Management is an output of that meeting which was interdisciplinary, reviewing existing knowledge, highlighting recent research findings and linking results from the natural with the social sciences. The special issue explores the 
complexity of exploited wetland ecosystems and how this knowledge can support wetland governance and wise use. A number of papers presented at the INTECOL Conference were related to the 'Ecology of Livelihoods' project funded by the Netherlands Government through a grant to UNESCO-IHE (van Dam et al. 2011). Additional contributions were made by other papyrus researchers. In this overview paper, we introduce papyrus wetlands against the background of the ecosystem services framework, place the current research activities in the context of earlier research on papyrus, and highlight some of the future research priorities.

\section{Ecological and hydrological characteristics of papyrus wetlands}

Cyperus papyrus belongs to the cosmopolitan family Cyperaceae (sedges), which comprise over 100 genera with about 5,000 species of widely varying appearance and natural history (Haines and Lye 1983). About 70 species occur in the African savannah zone and many are aquatic (Raynal-Roques 1980). Some Cyperus species look similar to C. papyrus, such as C. giganteus Vahl (giant flatsedge or Mexican papyrus) in Latin America and $C$. alternifolius L. (umbrella papyrus or umbrella sedge) which is grown in Europe and northAmerica as an ornamental plant (Heckman 1998; ARS-GRIN 2013). However, none of them reach the same height as papyrus, which grows to a maximum of 5-6 m.

The formation of extensive papyrus wetlands in eastern and central Africa was influenced strongly by the geological processes of the western Lake Victoria basin in the late Pleistocene, resulting in the formation of numerous mildly sloping valleys and floodplains with optimal conditions for papyrus vegetation: more or less permanently waterlogged soil, and intermediate current velocities and wave action (Beadle 1974; Thompson 1976). Until the late 18th century, papyrus occurred abundantly in lower Egypt in marshes along the river shores, much like the Sudd at present (Tä ckholm 1976). There are no reports about its occurrence in eastern, central and southern Africa from that period, but it was probably abundant in the large river and lake basins.

After the early 19th century, papyrus disappeared from Egypt except from a few places where it has been re-introduced (Serag 2003). In sub-Saharan Africa, papyrus wetlands remain extensive in the floodplain wetlands of the upper Nile basin in Uganda and in the Sudd in South Sudan, in the lacustrine and floodplain wetlands along Lake Victoria and its catchment, in the Congo and Zambezi river basins (e.g. the Bangweulu and Kafue flats) and the Okavango delta (Botswana) in the south. C. papyrus still occurs at Lake Huleh in the upper Jordan valley of Israel, where about $3 \mathrm{~km}^{2}$ of papyrus remained after conversion of the originally much larger papyrus swamp in the 1950s (Furth 1976). The northernmost occurrence, recorded since Roman times, is in Sicily (Malerba 1968). Lake Chad is the most western significant occurrence. Papyrus is rare in West Africa (Beadle 1974; Thompson 1985), although its presence has been reported from Nigeria (Ita 1994), Benin (Hughes and Hughes 1992), Guinea, Côte d'Ivoire and Benin (Beadle 1974) and the Gambia (Fillinger et al. 2009). The reason for its rareness in West Africa is not known but may be related to the strong seasonality of the rivers (Beadle 1974; Thompson 1976). 
In many papyrus wetlands, seasonal weather dynamics (one or two rainy seasons) produce distinct permanent and seasonally inundated zones, leading to zonation in soil moisture and vegetation. In the permanent zone, papyrus is extremely productive and can outcompete most other aquatic plant species, resulting in almost pure stands of $C$. papyrus. Diversity is low because of the shading by the papyrus canopy and the high load of decaying organic matter, favouring a few species well-adapted to low dissolved oxygen concentrations and low pH (Chapman et al. 2002). In East Africa, other plant species often associated with papyrus are Miscanthidium sp., Phragmites sp. and Typha sp. (Rzoska 1974; Denny 1984). Saunders et al. (2007) reported mean aboveground and belowground standing biomass in Kirinya wetland, Uganda of 2.26 and $7.13 \mathrm{~kg}$ of dry matter per $\mathrm{m}^{2}$, respectively. Average net primary production over a 6 months period was $22.1 \mathrm{~g} \mathrm{~m}^{-2}$ day $^{-1}$. This high productivity compared with other aquatic macrophytes and terrestrial herbaceous vegetation is partly explained by the C4 photosynthetic pathway (Jones and Muthuri 1997; Boar et al. 1999; Mnaya et al. 2007).

Drying conditions and removal of papyrus vegetation lead to an increase in plant diversity, as more drought-tolerant species can compete with papyrus. The drier periods allow access for livelihoods activities such as agriculture, livestock herding and vegetation harvesting. The papyrus vegetation can recover during the rainy season when the dry zone is re-flooded, unless permanent changes are made to vegetation, water or soils by digging channels or removal of rhizomes (e.g. in Namatala wetland Uganda; Namaalwa et al. 2013). On a longer time scale, the existence of papyrus wetlands is influenced strongly by the effects of climate and hydrological conditions through changes in lake levels, riverine discharge and lake seiches. During the second half of the 2oth century, the conditions for papyrus wetlands in the Lake Victoria region were influenced strongly by rainfall. The major event in the 20th century was the drastic increase in the level of Lake Victoria in 1961-1964 as a result of the Uhuru rains (Khisa et al. 2013). Many of the current fringing wetlands of the lake were formed at that time, while the existing wetlands were drowned (Thompson 1976). Changes in water depth and flooding regimes are, and will be, further affected by climate change. Erratic rainfall patterns have led to exceptionally dry years during which wetlands are affected by low water flows that facilitate more intense human exploitation, as observed e.g. in 2004-2005 in the Nyando wetland,

Kenya (Rongoei et al. 2013). Similarly, inundated areas in the Okavango Delta vary as a result of the high inter-annual variability of inflows, the major driver of hydrological and ecological processes in this wetland (Mazvimavi and Wolski 2006). Modification of the natural variability of inflows through upstream development of dams for irrigation and hydropower generation provide further potential for changes in the spatial distribution of the swamps and floodplains of the Okavango Delta wetland and their fauna (MurrayHudson et al. 2006). 
The high productivity and unique environment of papyrus wetlands make them an important habitat for many animals, including several endemic bird species (e.g. the papyrus gonolek, Laniarius mufumbiri; and the white-winged warbler, Bradypterus carpalis) (Gichuki and Gichuki 1992; Maclean et al. 2006), migratory birds (Ramsar 2013), and mammals (e.g. hippopotatmus, Hippopotamus amphibius; the sitatunga or marshbuck Tragelaphus spekii and the southern lechwe Kobus lechwe or Nile lechwe Kobus megaceros; IUCN SSC Antelope Specialist Group 2008). Papyrus wetlands also provide a refuge and a nursery for fish populations, including the Lake Victoria cichlids (Chapman et al. 2002; Mnaya et al. 2006).

Human-induced change has led to widespread degradation of papyrus wetlands. The overriding indirect driver behind this is population growth. The population of sub-Sahara Africa is expected to grow from about 850 million now to around 1.7 billion in 2,050. Not only the size, but also the average income level of the population will increase, and the demand for food will rise accordingly (Hachigonta et al. 2013). Economic development has been strong in Africa, with real GDP growth of $5 \%$ in 2012, expected to remain at that level for the next few years (UNECA 2013). Wetlands have always been foci of livelihoods activities because of the ample supplies of fish, biomass, water and other resources. The increasing demand for food and other materials, in combination with droughts that make upland agriculture more risky, has intensified farming in wetlands (Wood and van Halsema 2008; Rebelo et al. 2010). Increasingly, wetlands are reclaimed permanently for large scale farming, often through corporate or government activity (e.g. in the Yala wetland, Kenya; Kinaro 2008).

The exact geographical extent of papyrus wetlands is not known, and it is impossible to make a reliable loss coefficient of $3 \%$ per year or higher). The implications for fauna associated with papyrus may be even more severe, because of habitat fragmentation and general degradation (Maclean et al. this volume). 


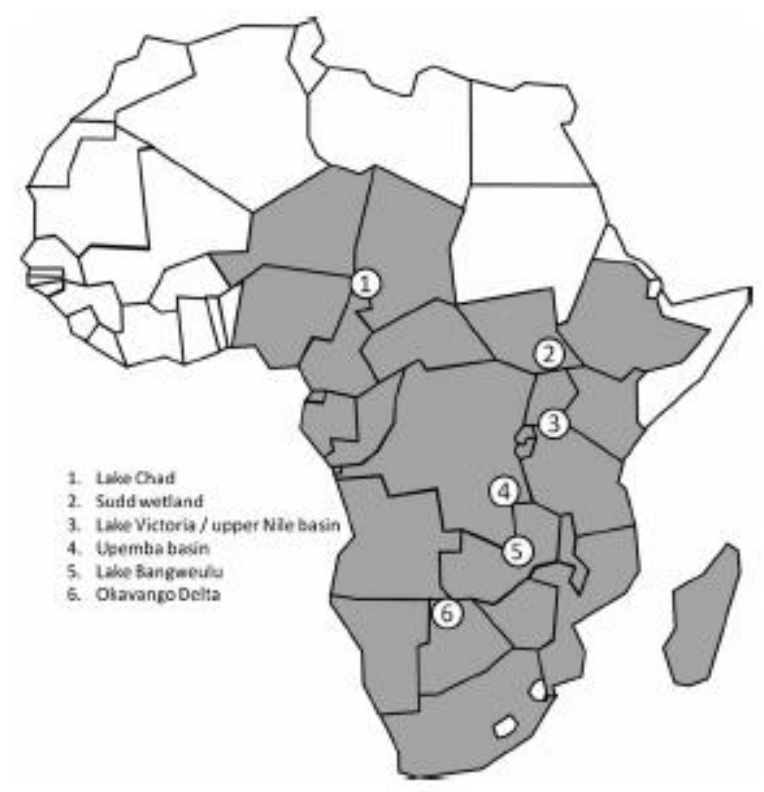

Fig. 1 Schematic map of Africa showing countries where $C$. papynus occurs in grey. Numbers indicate some major papyrus wetland ecosystems

Table 1 Estimates of papyrus wetland degradation based on some published studies and an exponential decay model

\begin{tabular}{|c|c|c|c|c|}
\hline Wetland system & Period & Size range $\left(\mathrm{km}^{2}\right)^{a}$ & $\begin{array}{l}\text { Loss coefficient k } \\
\left(\text { year }^{-1}\right)^{\mathrm{b}}\end{array}$ & Source \\
\hline Lake Naivasha, Kenya & $1960-1995$ & $48>14$ & -0.053 & Boar et al. (1999) \\
\hline $\begin{array}{l}\text { Nyando river wetlands, Kenya } \\
\text { (Dunga, Koguta, Kusa) }\end{array}$ & $1969-2000$ & $57.5>32.3$ & -0.019 & Owino and Ryan (2007) \\
\hline Yala swamp, Kenya & 1970-2005 & $175>106$ & -0.014 & Kinaro (2008) \\
\hline Namatala wetland, Uganda & $1990-2010$ & $22>12$ & -0.029 & Namaalwa et al. (2013) \\
\hline Upper Nile basin & $1985-2000$ & $1,643>1,532$ & -0.0047 & Maclean et al. (this vol.) \\
\hline
\end{tabular}

\section{Importance of papyrus wetlands: ecosystem services and sustainable use}

Since around 2600 BC, papyrus was used for producing paper in ancient Egypt (Muccigrosso 2013; Seid 2013) but human use of papyrus products can be assumed to be much older. Papyrus paper was popular in ancient Greece and Rome but its importance diminished in the early Middle Ages when it was replaced by parchment and rag paper (Shepherd 2008). Because of this reduced economic importance, papyrus in the Egyptian Nile valley was replaced largely by agriculture by the early 19th century (Smith 1973; Tä ckholm 1976). Papyrus wetlands are still important for millions of Africans and have long been part of the cultural tradition of wetland communities such as the Nilotic people of East Africa (the Dinka, Nuer and Shilluk in Sudan and the Luo in Kenya) for whom adaptation to the wetland and its seasonal dynamics is a part of daily life (Rzoska 1974). Many people traditionally supported their livelihoods using wetland resources, with a combination of seasonal fishing, livestock herding and wetland and upland agriculture (Geheb and Binns

\section{http://repository.uwc.ac.za}


1997). Traditional use of papyrus wetlands as sacred places is gradually disappearing (Kibwage et al. 2008), but the wetlands still play an important role in beliefs, ceremonies and as burial sites. Significant indigenous knowledge (e.g. about the nutritional and medicinal use of wetland plants; Geissler et al. 2002) exists among human communities closely connected with wetlands. Papyrus wetlands can have a wider importance and high future potential as tourist destinations, as exemplified by the Okavango delta.

The importance of wetlands can be expressed and understood within the framework of ecosystem services (MEA 2005; TEEB 2010; Maltby and Acreman 2011; Russi et al. 2013). Provisioning services are among the most visible and easily measured. Papyrus biomass is harvested widely for thatching and making mats, crafts, rafts, household utensils and decorations, and for fuel (Ojoyi 2006; Osumba et al. 2010). Different parts and growth stages of the plant are used for different purposes (e.g. different culm diameters for different types of thatching, umbels for making brooms, rhizomes for fuel). Other species of wetland vegetation are used as livestock fodder during the dry season or as medicinal plants. Papyrus wetlands supply food for human consumption through agriculture and livestock herding in the seasonally flooded zone (Rongoei et al. 2013). Papyrus wetlands are also important for fishing (Gichuki et al. 2001), both as nurseries and for fish production. Some attempts at integrated aquaculture in papyrus wetlands have remained experimental with little adoption by farmers (Denny et al. 2006; Kipkemboi et al. 2007). Drinking water supply is also important, both to riparian populations through local wells and boreholes and as a source for drinking water production for urban centers (Barakagira and Kateyo 2008; Byaruhanga and Kigoolo 2005). Wetland harvests of vegetation and fish are often not reflected adequately in national accounting frameworks and therefore their contirubtion to the national economy is underestimated (Moyini et al. 2002).

The regulating services of papyrus wetlands are often alluded to but rarely quantified. These include water quality regulation by retention of carbon, nutrients, trace elements and sediment; water quantity regulation (water storage, flood protection) and cli- mate regulation (e.g. effects on air humidity and rainfall). Nutrient removal by fringing wetlands is often seen as the cause of good water quality in the downstream water body. While papyrus can surely trap nutrients and sediment (Boar and Harper 2002) and seems efficient at removing nutrients compared with other plant species (Azza et al. 2000; Kyambadde et al. 2004), nutrient retention depends on the hydrological connectivity between river/lake and wetland. Some wetlands flood only briefly, with limited exchange between wetland and water body for the rest of the year and limited impact of the wetland on nutrient concentrations. Under flooded conditions, papyrus can sequester large amounts of carbon $\left(1.6 \mathrm{~kg} \mathrm{C} / \mathrm{m}^{2} /\right.$ year; Jones and Humphries 2002), but this can be released again as dissolved organic carbon (DOC) from leaching or as $\mathrm{CO}_{2}$ when accumulated organic matter is exposed during drawdown (Jones and Humphries 2002; Mwanuzi et al. 2003; Loiselle et al. 2008). The spatial scale at which retention is considered is also important. Studies on constructed wetlands consider nutrient removal efficiency which is based largely on nutrient accumulation in soil and vegetation (Kivaisi 
2001; Rousseau et al. 2004). On a catchment scale, nutrient accumulation in the wetland does not contribute to nutrient removal and only nitrogen is definitely removed through denitrification. Papyrus vegetation also influences the water balance in a catchment. Several studies show that evapotranspiration in papyrus wetlands $(1,500-1,600 \mathrm{~mm} / \mathrm{year})$ was lower than in open water (Butcher 1938; Mohamed et al. 2004; Jones and Humphries 2002). Wetland vegetation, especially in large systems like the Sudd, the Okavango and Lake Victoria basin reduces runoff and has a positive effect on moisture recycling, thus contributing to rainfall in the catchment (Savenije 1995b). Draining of wetlands and conversion to crops or other land uses is therefore likely to have an impact on rainfall and local and regional climate (Savenije 1995a).

The Ramsar Convention on Wetlands defines 'the wise use of wetlands' as the 'maintenance of their ecological character, achieved through the implementation of ecosystem approaches, within the context of sustainable development' (Finlayson 2012). Using the ecosystem services concept, this definition could be rephrased as 'the long-term use of one or several of the wetland's ecosystem services without degrading or losing other ecosystem services' (see e.g. de Groot et al. 2010). According to this definition, agriculture would be sustainable if it enhances the provisioning services of wetlands without disproportionately affecting the regulating, cultural and habitat services. However, agricultural activities frequently lead to permanent alterations to soil and water flows of the wetland which affect the regulating services (e.g. Kansiime et al. 2007). Decision making in wetland management should involve the evaluation of these trade-offs among ecosystem services (McCartney et al. 2010). Prerequisite for this are quantification and economic valuation of all ecosystem services and an agreement among stakeholders about desirable levels of the various services. As this is generally more difficult for regulating than for provisioning services, the former are often estimated with less certainty or ignored in feasibility studies for new developments (Emerton et al. 1999). Despite numerous studies showing that the economic value of intact wetlands (including their regulating and cultural services) is higher than the value of converted wetlands (Barbier and Thompson 1998; Balmford et al. 2002; de Groot et al. 2010), conversion of wetlands is often still based on short-term gains from provisioning services, driven by governmental policies and associated subsidies. Better evidence to support decisions, including the use of hydrological and ecological models, is needed for quantifying the value of regulating services.

\section{Research on papyrus wetlands}

Initially, research on papyrus wetlands was focused on gathering knowledge for increasing the economic benefits of these ecosystems, e.g. through fishing, forestry or agriculture. Early publications on papyrus include reports on the biology of three swamps in Uganda from the Cambridge expedition to the east African lakes (Beadle 1932) and the diversity of flora and fauna in a Ugandan papyrus wetland before and after conversion to a forest plantation (Eggeling 1934, 1935). The period between 1940 and the mid 1980s resulted in sporadic but important publications. In the 1950s, surveys were conducted in the Nile swamps (e.g. Talling 1957; see also Rzoska 1976). In the same period, scientists at Makerere University, Kampala and at the East African Fisheries Research Organization in Jinja, 
Uganda, conducted studies on swamp biology, water quality and hydrology in various Ugandan papyrus wetlands (Carter 1956; Beadle 1957, 1958; Lind and Visser 1962). The transition to independence in several countries led to a pause in research on wetlands, but in the 1970 s and 1980 s interest in African freshwater wetlands was revived (e.g. Beadle 1974; Rzoska 1976; Denny 1985; Whig- ham et al. 1993).

Since the 1970s, research on papyrus wetlands has been more systematic and has covered a wider range of disciplines including ecology, biogeochemistry, hydrology and socioeconomics. The signing of the Ramsar Convention on Wetlands in 1971 sparked a renewed interest in wetlands research in Africa and resulted in an inventory of African wetlands (Hughes and Hughes 1992). Important research on papyrus ecology and biogeochemistry was done in the late 1970 s and 1980 s in Kenya (Gaudet 1977a, b; 1979), Tanzania (Jones and Muthuri 1985; Jones 1987), and DR Congo (then Zaire; Thompson et al. 1979), leading to much-needed basic knowledge about the productivity and nutrient uptake of papyrus wetlands that is still highly relevant for policy making today, and used as the basis for a number of modelling efforts. Several important research projects were conducted around the Sudd wetland, many of them related to the until now incomplete construction of the Jonglei Canal (Howell et al. 1988).

More recent research from the 1990 s to present have focused more on water and food security aspects and wise use of papyrus wetlands. For example, a major interdisciplinary study of Nakivubo wetland in Uganda (Kansiime and Nalubega 1999) showed the importance of this wetland for both water quality regulation and agriculture. Two EU-funded projects, Fingerponds (2002-2006) and Ecotools (2002-2005) focused on enhancing fish production through integrated pond aquaculture (e.g. Denny et al. 2006; Kaggwa et al. 2009; Kipkemboi et al. 2010) and on developing modelling tools for improved wetland management (Loiselle et al. 2006). Various other projects focused on wetlands such as the Sudd (Mohamed et al. 2004), Lake Naivasha (Boar et al. 1999; Boar 2006), Yala swamp (Thenya et al. 2006), northern Lake Victoria (Azza et al. 2006), Rubondo Island in Lake Victoria (Mnaya and Wolanski 2002; Mnaya et al. 2006, 2007), wetlands in western Kenya (Gichuki et al. 2001; Osumba et al. 2010; Morrison et al. 2012), and the Okavango Delta (McCarthy and Ellery 1994, 1998; Ellery et al. 1995). The EU-funded WETWIN project (2009-2011) incor- porated two papyrus wetlands (Namatala and Nabajuzzi) in Uganda and aimed at developing integrated approaches for management (Cools et al. 2013; Johnston et al. 2013). The Netherlands-funded ECOLIVE project (2009-2013) involved a transdisciplinary study of the Nyando wetland in Kenya, incorporating hydro- logical, ecological and socioeconomic sub-projects (van Dam et al. 2011, 2013). In addition to studies of the natural wetland environment, there were also various studies on papyrus in constructed wetlands for water quality regulation (Chale 1985, 1987; Okurut et al. 1999; Okurut 2001; Kyambadde et al. 2005; Abira et al. 2005). A number of economic valuation studies of papyrus wetlands were done (e.g. Emerton et al. 1999; Mmopelwa 2006). 


\section{Policy development and management approaches for papyrus wetlands}

The Ramsar Convention promotes the 'wise use' concept, which allows for incorporation of multiple uses and interests into management objectives, including biodiversity, water and food security, and water quality and quantity regulation (Finlayson 2012). While this presumes a good understanding of ecohydrological dynamics, policies are often not supported adequately by research. Besides ecological studies on the impact of exploitation, pollution and physical modification on key species and biodiversity, there is a need for integrated interdisciplinary research that includes socioeconomic and governance aspects of wetlands. This would help to link knowledge about the resilience of the ecosystem to a better understanding of decision making, both directly at the level of exploitation of the wetland ecosystem as well as at the level of policy formulation and implementation (Rebelo et al. 2010; van Dam et al. 2013).

As an example, the integrated Okavango Delta Management Plan (ODMP) incorporates key elements of sustainability, such as creating a viable institutional framework, conservation of the provision of ecosystem services, and sustainable use of wetland resource for supporting livelihoods (DEA 2008; Magole and Kgomotso 2010). Planning was based on participation of key stakeholders such as communities and government agencies responsible for managing resources within the delta. A major concern in implementation is that government agencies use a centralized, sectoral approach and delta issues may not always have the same priority in the different sectors (Magole 2008). One of the major benefits of the ODMP was that countries sharing the Okavango River basin adopted an integrated strategic action programme that covered the whole basin.

Even when policies and legislation aimed for sustainability and environmental protection are in place, implementation and enforcement remain a challenge. Uganda was one of the first counties with a wetland policy (WID/IUCN 2005; WMD/NU 2008) and several Ugandan papyrus wetlands have a protected status (e.g. Nabajjuzi wetland, Lake George and Murchison Falls are Ramsar sites). The knowledge base for papyrus wetlands is considerable (Nakivubo wetland in Kampala was the subject of significant research projects, including an economic valuation study; Kansiime and Nalubega 1999; Emerton et al. 1999). Despite these favourable circumstances, wetland protection efforts in Uganda struggle with conflicting interests among government sectors, lack of clarity about responsibilities and financial resources in a highly decentralized governance system, and tensions between formal and traditional land use arrangements (Hartter and Ryan 2010; Namaalwa et al. 2013).

Of the current 47 countries that are signatories to the Ramsar Convention in Africa, 28 have papyrus wetlands, some of which are wetlands of international importance ('Ramsar sites'). Despite this recognition of their importance, papyrus wetlands are often regarded as wastelands and appreciation among local users and policy makers about local and international benefits is limited. There are many policy conflicts, e.g. with agriculture or urban development and there is a need to improve implementation and cross compliance of wetland policy once it has passed the legislative and administrative processes. 


\section{Future research and policy for papyrus wetlands: lessons learned and recommendations}

While knowledge of papyrus wetlands is considerable, this knowledge is not often translated to effective management. In this last section the lessons learned from the synthesis in the previous sections are summarized and illustrated using the contributions in this special issue.

A prime conclusion is that current estimates of the area covered by papyrus wetlands are inaccurate, in part due to the dynamic nature of the wetlands and in part due to lack of resources devoted to wetland management in national governments. Wetland inventories are part of the commitments of Ramsar countries, but less than 40 \% of the African Ramsar signatories have completed them (Ouedraogo 2013). A better assessment of the areal extent of papyrus wetlands is needed, e.g. by analyzing national inventory databases. As papyrus wetlands are not always easily accessible and field work presents certain risks (e.g. of dangerous wildlife or water-borne diseases), earth observation techniques can provide important information about changes in vegetation coverage and other indicators, as shown in the GlobWetland projects of the European Space Agency and the Ramsar Convention (Fuller et al. 1998; Ozesmi and Bauer 2002; Jones et al. 2009).

The study by Maclean et al. (this volume) estimates the decline of papryus wetlands in the upper Nile basin between the mid-1980s and 1999-2001 based on ground-truthed Landsat images. Results show that papyrus wetlands disappear at a faster rate $(6.7 \%$ in about 15 years) than emergent wetlands generally (2.2\%). Estimates of the occurrence of five bird species associated with papyrus (based on regression models of occurrence and habitat characteristics) showed that the decline of the avifauna was much higher (ranging from 12.7 to $42.2 \%)$. The authors recommend increased attention for wetlands that hold relatively high densities of these key species. These may be other sites than those currently designated as IBA (Important Bird Area) or Ramsar sites.

Inventories of wetlands should include a compre- hensive assessment of ecosystem services categories. Several methods for assessment of biodiversity, eco- system health and ecosystem services have been developed and could be adapted to local conditions (CBD/Ramsar 2006; Groot et al. 2006; Kotze et al. 2008; Maltby 2009; Kotze 2010; Peh et al. 2013). Biomass harvesting, fishing and cultivation enhance the provisioning services but can reduce regulating services or biodiversity. Knowledge about these interactions is needed for formulating and comparing alternative management scenarios and for trade-off analyses. Assessments should include the drivers of change impacting on the wetland, and interactions between services and drivers.

Morrison et al. (this volume) provide an example of a study which aims at enhancing the provisioning services of papyrus wetlands by combining a sustain- able harvesting technique with locally available technology for adding value to papyrus products. Their study shows that it is possible to selectively harvest up to $90 \%$ of the biomass, leaving 
young culms intact and thus maintaining the regenerative capacity of the wetland for repeated harvesting. Novel carbonized briquettes were produced from the papyrus culms using locally manufactured tools. The briquettes compare favourably with wood charcoal in terms of calorific value and use characteristics. This work shows that new provisioning ecosystem services can be explored, increasing the use value of the wetland while sparing the regulating functions (nutrient uptake by re-growing papyrus) and with a positive effect on other ecosystems (e.g. reduced pressure on forests for firewood).

Regulating services are more difficult to quantify than provisioning services and less frequently studied. Saunders et al. (this volume) review C storage in papyrus wetlands and estimated it at $88 \mathrm{t} \mathrm{C} / \mathrm{ha}$ in biomass, comparable with forest ecosystems, and $640 \mathrm{t}$ $\mathrm{C} /$ ha in peat under permanently flooded papyrus. The latter far exceeds carbon stored in tropical forests, but some caution with respect to the stability of this $\mathrm{C}$ store is in order. Owing to natural hydrological variation a drawdown can cause exposure and decomposition of detritus and peat deposits. Climate change may increase the risk of these events, thereby threatening the stability if this $\mathrm{C}$ store even more. Another caution is the potential emission of greenhouse gases by papyrus wetlands. Limited evidence from field measurements shows that payrus wetlands may produce significant emissions of methane and nitrous oxide. More research is needed to quantify these processes that counteract the climate change mitigation effect of these ecosystems.

Another challenge in the research into ecosystem services is that provisioning and regulating services are often realized at different spatial and temporal scales. Provisioning services are often most important for local resource users and communities, while regulating services such as nutrient and sediment regulation can be important for communities in downstream parts of the catchment. These spatial and temporal 'trade-off asymmetries' (Rodr'iguez et al. 2006; Carpenter et al. 2009) depend on a range of factors including their hydrological connectivity, the community structure of the vegetation and the socio- economic condition and wetland use strategies of the communities depending on the wetland. Because of this complexity, a full understanding of regulating services can be achieved only by integrated ecohydrological and socio-economic studies which link field and remote sensing data to models of water and nutrient cycles with human use (e.g. Simonit and Perrings 2011). This is important for decision-making and determining trade-offs with provisioning services and agricultural development.

An example of a simulation model that predicts the flow of carbon and nitrogen through a rooted papyrus stand is given by Hes et al. (this volume). The model consists of sub-models for the seasonally and permanently flooded zones and calculates nitrogen retention in the wetland in relation to changes in hydrology and different harvesting scenarios. Without harvesting nitrogen retention was around $22 \mathrm{~g} \mathrm{~N} / \mathrm{m}^{2} /$ year. Harvesting reduces the biomass of the papyrus stand, stimulates re-growth and increases nitrogen uptake. Two harvesting approaches were evaluated: annual batch harvesting up to $100 \%$ of the aboveground biomass, and daily selective harvesting. Above harvesting rates of 90 
$\mathrm{g} / \mathrm{m}^{2} /$ day, the papyrus collapsed. Calculations with this model can assist in quantifying the effect of different management strategies on the regulating services of papyrus wetlands and can serve as the basis for economic valuation.

Changes in water level and exploitation can also influence the vegetation structure of papyrus wetlands. A study of the composition of the papyrus vegetation in Nyando wetland, Kenya in undisturbed and con- verted zones under dry and wet conditions (Rongoei et al. this volume) showed that in the undisturbed zones, where soil moisture remains high even during the dry season, the vegetation was dominated by obligate and facultative wetland species (mostly $C$. papyrus and $V$. cuspidata). In the zones affected by human activities such as cropping, vegetation harvest- ing, burning and livestock herding, there were oppor- tunities for dryland species as shown by higher species richness and diversity index. Most of these livelihoods activities result in further reduction of soil moisture (e.g. canalization, removal of wetland vegetation) which poses a risk of permanent alteration of the flooding regime.

On a larger scale, the study by Mohamed and Savenije (this volume) investigates the longterm dynamics (100 years) of the hydrology of the Sudd wetland. The study emphasizes the strong links between a large wetland ecosystem and both local (surrounding) and regional (upstream) areas. Precipitation and evaporation over the Sudd showed no significant upward or downward trend over the last 100 years, and all changes in the size of the wetland were caused by changes in inflow from the White Nile. The surprising lack of trend in evaporation from the wetland, desipte a clear upward trend in temperatures (0.6 and $1.5{ }^{\circ} \mathrm{C}$ for daily maximum and minimum temperature, respectively) was related to a decrease in relative humidity and solar radiation over the Sudd. The water balance in the Sudd is thus related strongly to the climate over the Lake Victoria region, and the rainfall there in the early 1960 s has led to a doubling in size of the Sudd which still persists at present. This improved understanding of the Sudd hydrology will be important in the Jonglei canal discussions, which may be re-opened.

Given the major background processes driving change in wetlands (population growth/economic development and climate change), African nations will look for ways to increase food security through growing agricultural production in the coming years (Chauvin et al. 2012; Hachigonta et al. 2013). More than ever, effective wetland management approaches will be needed if the rapid rate of degradation of papyrus wetlands is to be slowed down or even reversed. With more variability in rainfall causing more uncertainty in traditional rainfed agriculture, wetlands will increasingly be targeted for agricultural development. Examples can be seen in e.g. the Bugesera area in northeast Rwanda, in the Yala and Nyando wetlands in Kenya, and in Namatala wetland in Uganda. For wetlands with valuable or unique habitat, regulating or cultural services, governments should consider mechanisms for protecting these ecosystems, including restrictive approaches to agri- cultural development. For valuable sites that are degraded, options for wetland restoration should be considered (Morrison et al. 2012; Kiwango et al. 2013). For 
other wetlands some form of integrated management with a balance between ecosystem services, including a certain level of agricultural and fisheries development (provisioning services) will be a more realistic goal.

A systematic approach to integrated wetland management, as used succesfully in European wetlands, was applied to the Namatala papyrus wetland in Uganda by Zsuffa et al. (this volume). Their study highlights the challenges of quantifying the regulating ecosystem services of the wetland without the avail- ability of regular monitoring data and quantitative ecohydrological models. The study demonstrates the benefits of a participatory approach that involves all stakeholders and of a comprehensive assessment of management objectives across the wide range of ecosystem services. Even if there is room for improvement of the valuation, the joint understanding of the importance of all wetland benefits among sometimes competing stakeholders is invaluable.

Some agricultural and aquacultural practices are more damaging to wetland ecosystems than others, and research should aim at adapting sustainable culture technology for application in wetlands. For this, more collaboration between agronomists/aquaculturists and wetland scientists and practitioners is needed. Crop and fish cultivation in wetlands could be made more sustainable by using nutrients more efficienctly and reducing fertilizer inputs through integrated agriculture-aquaculture, by reducing pesticide use through integrated pest management, by preventing erosion, and by smarter forms of waste management and nutrient recycling (Pretty 1999; FAO 2011). With respect to the latter, the use of papyrus in constructed wetlands and buffer zones can be consid- ered. More research is needed into the lack of adoption of promising constructed wetland technology in Africa (Kivaisi 2001).

Another vital area of research which deserves more attention is the governance of African wetland ecosystems. African governments have started developing wetland policies, but traditional governance systems evolved during centuries of living in and depending on wetlands. While traditional systems are no safeguard against wetland degradation in modern times, new policies could benefit from analyzing and incorporating successful traditional institutional arrangements. Effective wetland management, even when wetland policies exist, has been shown to suffer from unclear land ownership arrangements and from conflicts among resource users and between resource users and local or national governments. A better understanding of the motivation of riparian communities to utilize papyrus wetlands (as affected by factors like level and source of household income, education, gender, and age) is needed (see e.g. Mwakubo and Obare 2009; Morrison et al. 2012). How can awareness of the importance of wetland integrity for livelihoods be enhanced? How can the strengths of traditional communal governance and modern legislation be combined to increase the social capital and adaptive capacity of the wetland social- ecological systems? (Adger 2000; Gupta et al. 2010). A better understanding among decision makers of how biodiversity, water resources, climate change and environmental integrity interact with food security, institutions and natural, human and economic capital 
seems a prerequisite for improving the quality of decision making compared with the current, often one-sided sectoral approaches (Hanjra and Qureshi 2010).

\section{Conclusion}

The need for using wetlands responsibly to sustain livelihoods and increase human wellbeing is increasingly recognized (Russi et al. 2013; Wood et al. 2013). African papyrus wetlands offer an excellent opportunity to implement the principles of 'wise use' because of their high productivity and rapid recovery after disturbance, their high potential for contributing to water quality and climate regulation, their importance in supporting livelihoods and their abundant presence throughout eastern and southern Africa. Nevertheless, papyrus is disappearing rapidly, and there is consid-rable uncertainty about the impact on papyrus wetlands of population growth, economic develop- ment, climate change and the need for African countries to ensure food security. Countries with papyrus wetlands need to increase attention for the protection of these vital resources. Tools are available for resource and ecosystem services assessment and for determination of tradeoffs, as well as good examples of integrated management plans. Research should focus on a better understanding of the processes underlying the regulating services of papyrus wetlands, on economic valuation of all ecosystem services, and on effective, inclusive governance systems that enhance the resilience of papyrus wetlands and all people that depend on them. This special issue brings together some recent findings important for that process, and hopefully will stimulate further interdisciplinary research to promote our understanding of these important ecosystems.

\section{Acknowledgments}

This work was supported by the Netherlands Ministry of Foreign Affairs through the programmatic cooperation between the Directorate General for International Cooperation (DGIS) and UNESCO-IHE Institute for Water Education. 


\section{References}

Abira MA, van Bruggen JJA, Denny P (2005) Potential of a tropical subsurface constructed wetland to remove phenol from pre-treated pulp and papermill wastewater. Water Sci Tech 51:173-176

Adger WN (2000) Social and ecological resilience: are they related? Prog Hum Geogr 24:347-364. doi:10.1191/ 030913200701540465

ARS-GRIN (2013) Germplasm resources information network (GRIN). United States Department of Agriculture, Agricultural Research Service, Beltsville Area. http://www.arsgrin.gov

Azza NGT, Kansiime F, Nalubega M, Denny P (2000) Differ- ential permeability of papyrus and Miscanthidium root mats in Nakivubo swamp, Uganda. Aquat Bot 67:169-178

Azza NGT, Denny P, van de Koppel J, Kansiime F (2006) Floating mats: their occurrence and influence on shoreline distribution of emergent vegetation. Freshw Biol 51:1286-1297

Balmford A, Bruner A, Cooper P, Costanza R, Farber S, Green RE, Jenkins M, Jefferiss P, Jessamy V, Madden J, Munro K, Myers N, Naeem S, Paavola J, Rayment M, Rosendo S, Roughgarden J, Trumper K, Turner RK (2002) Economic reasons for conserving wild nature. Science 297:950-953

Barakagira A, Kateyo E (2008) Impacts of wetland drainage on domestic water supplies and people's livelihoods in Kabale district, Uganda. Paper presented at the 12th Biennial Conference of the International Association for the Study of Commons, University of Gloucestershire, UK. http:// iasc2008.glos.ac.uk/conference\%2opapers/papers/B/

Barbier EB, Thompson JR (1998) The value of water: floodplain versus large-scale irrigation benefits in northern Nigeria. AMBIO 27:434-440

Beadle LC (1932) Scientific results of the Cambridge Expedi- tion to the East African Lakes, 1930-1.-3. Observations on the bionomics of some East African Swamps. J Linn Soc Lond Zool 38(258):135-155

Beadle LC (1957) Respiration in the African swampworm Alma emini Mich. J Exp Biol 34:110

Beadle LC (1958) Hydrobiological investigations on tropical swamps. Verh internat Ver Limnol 13:855-857

Beadle LC (1974) The inland waters of tropical Africa. An introduction to tropical limnology. Longman Group, Lon- don, p 365

Boar RR (2006) Responses of a fringing Cyperus papyrus L. swamp to changes in water level. Aquat Bot 84:85-92

Boar RR, Harper D (2002) Magnetic susceptibilities of lake sediment and soils on the shoreline of Lake Naivasha, Kenya. Hydrobiologia 488:81-88

Boar RR, Harper DM, Adams CS (1999) Biomass allocation in Cyperus papyrus in tropical wetland, Lake Naivasha, Kenya. Biotropica 31(3):411-421

Butcher AD (1938) The Sudd hydraulics. Ministry of Public Works, Cairo

Byaruhanga A, Kigoolo S (2005) Nabajjuzi wetland system ramsar information sheet. Nature Uganda.

http://www. ramsar.wetlands.org/RamsarSitesInformationService/tabid/ 719/Default.aspx 
Carpenter SR, Mooney HA, Agard J, Capistrano D, DeFries RS, D'iaz S, Dietz T, Duraiappah AK, Oteng-Yeboah A, Pereira HM, Perrings C, Reid WV, Sarukhan J, Scholes RJ, Whyte A (2009) Science for managing ecosystem services: beyond the millennium ecosystem assessment. Proc Natl Acad Sci USA 106:1305-1312

Carter GS (1956) The Papyrus swamps of Uganda. W. Heffer \& Sons Ltd., Cambridge, p 25

CBD/Ramsar (2006) Guidelines for the rapid ecological assessment of biodiversity in inland water, coastal and marine areas. CBD Technical Series no. 22/Ramsar Technical Report no. 1. Secretariat of the Convention on Biological Diversity, Montreal, Canada and Secretariat of the Ramsar Convention, Gland, Switzerland

Chale FMM (1985) Effects of Cyperus papyrus L. swamp on domestic wastewater. Aquat Bot 23:185-189

Chale FMM (1987) Plant biomass and nutrient levels of a tropical macrophyte (Cyperus papyrus L.) receiving domestic wastewater. J Aquat Ecol 21:167-170

Chapman LJ, Chapman CA, Nordlie FG, Rosenberger AE (2002) Physiological refugia: swamps, hypoxia, tolerance and maintenance of fish diversity in the Lake Victoria region. Comp Biochem Physiol A 133:421-437

Chauvin ND, Mulangu F, Porto G (2012) Food production and consumption trends in SubSaharan Africa: prospects for the transformation of the agricultural sector. United Nations Development Program, Regional Bureau for Africa. UNDP Working Paper 2012-011. http://www.undp. org/content/rba/en/home/library/workingpapers/food- production-consumption-trends/

Cools J, Johnston R, Hattermann FF, Douven W, Zsuffa I (2013) Tools for wetland management: lesson learnt from a comparative assessment. Environ Sci Policy 34:138-145

Darwall WRT, Smith KG, Allen DJ, Holland RA, Harrison IJ, Brooks EGE (eds) (2011) The Diversity of Life in African Freshwaters: Under Water, Under Threat. An analysis of the status and distribution of freshwater species throughout mainland Africa. IUCN, Cambridge

de Groot RS, Stuip MAM, Finlayson CM, Davidson N (2006) Valuing wetlands: guidance for valuing the benefi ts derived from wetland ecosystem services, Ramsar Tech- nical Report No. 3/CBD Technical Series No. 27. Ramsar Convention Secretariat, Gland, Switzerland \& Secretariat of the Convention on Biological Diversity, Montreal, Canada

de Groot RS, Alkemade R, Braat L, Hein L, Willemen L (2010) Challenges in integrating the concept of ecosystem ser- vices and values in landscape planning, management and decision making. Ecol Complex 7:260-272

DEA (2008) Okavango Delta Management Plan. Department of Environmental Affairs, Ministry of Environment, Wildlife and Tourism, Government of Botswana, Gaborone, p 191

Denny P (1984) Permanent swamp vegetation of the Upper Nile. Hydrobiologia 110:79-90 Denny P (ed) (1985) The ecology and management of African wetland vegetation. Dr W Junk Publishers, Dordrecht 
Denny P, Kipkemboi J, Kaggwa R, Lamtane H (2006) The potential of Finger pond systems to increase food produc- tion from wetlands in Africa. Int J Ecol Environ Sci 32:41-47

Eggeling WJ (1934) Notes on the flora and fauna of a Uganda swamp. Uganda J 1:51-60

Eggeling WJ (1935) The vegetation of Namanve swamp, Uganda. J Ecol 23:422-435

Ellery WN, Ellery K, Rogers KH, McCarthy TS (1995) The role of Cyperus papyrus L. in channel blockage and abandon- ment in the northeastern Okavango Delta. Botswana. Afr J Ecol 33:25-49

Emerton L, Iyango L, Luwum P, Malinga A (1999) The present economic value of Nakivubo urban wetland, Uganda. IUCN and National Wetlands Programme, Kampala

FAO (2011) The state of the world's land and water resources for food and agriculture (SOLAW)-Managing systems at risk. Food and Agriculture Organization of the United Nations, Rome and Earthscan, London

Fillinger U, Sombroek H, Majambere S, van Loon E, Takken W, Lindsay SW (2009) Identifying the most productive breeding sites for malaria mosquitoes in The Gambia. Malar J 8:62. doi:10.1186/1475-2875-8-62

Finlayson CM (2012) Forty years of wetland conservation and wise use. Aquatic Conserv 22:139-143

Fuller RM, Groom GB, Mugisha S, Ipulet P, Pomeroy D, Ka- tende A, Bailey R, OgutuOhwayo R (1998) The integra- tion of field survey and remote sensing for biodiversity assessment: a case study in the tropical forests and wet- lands of Sango Bay, Uganda. Biol Cons 86:379-391

Furth DG (1976) The Huleh and its lost aquatic leef beetle. Atala 4(1-2):4-9

Gardner RC, Connolly KD, Bamba A (2009) African wetlands of international importance: assessment of benefits asso- ciated with designations under the Ramsar Convention. The Georgetown International Environmental Law Review XXI

Gaudet JJ (1977a) Uptake, accumulation, and loss of nutrients by papyrus in tropical swamps. Ecology 58:415-422

Gaudet JJ (1977b) Natural drawdown on Lake Naivasha, Kenya and the formation of papyrus swamps. Aquat Bot 3:1-47

Gaudet JJ (1979) Seasonal changes in nutrients in a tropical swamp: north swamp, Lake Naivasha, Kenya. J Ecol 67:953-981

Geheb K, Binns T (1997) 'Fishing farmers' of 'farming fisher- men'? The quest for household income and nutritional security on the Kenyan shores of Lake Victoria. Afr Aff 96:73-93

Geissler PW, Harris SA, Prince RJ, Olsen A, Odhiambo RA, Oketch-Rabah H, Madiega PA, Andersen A, Mølgaard P (2002) Medicinal plants used by Luo mothers and children in Bondo district, Kenya. J Ethnopharmac 83:39-54

Gichuki CM, Gichuki NN (1992) Wetland birds of Kenya. In: Crafter SA, Njuguna SG, Howard GW (eds) Wetlands of Kenya-Proceedings of the KWWG Seminar on Wetlands of Kenya, 3-5 July 1991. IUCN, Nairobi

Gichuki J, Dahdouh Guebas F, Mugo J, Rabuor CO, Triest L,

Dehairs F (2001) Species inventory and the local uses of the plants and fishes of the Lower Sondu Miriu wetland of Lake Victoria, Kenya. Hydrobiologia 458:99-106 
Gupta J, Termeer C, Klostermann J, Meijerink S, van den Brink M, Jong P, Nooteboom S, Bergsma E (2010) The adaptive capacity wheel: a method to assess the inherent characteristics of institutions to enable the adaptive capacity of society. Environ Sci Policy 13:459-471

Gevers I, Koopmanschap, E (2012) Enhancing the wise use of wetlands-a framework for capacity development. Centre for Development Innovation, Wageningen University \& Research Centre, Wageningen

Hachigonta S, Nelson GC, Thomas TS, Sibanda LM (eds) (2013) Southern African Agriculture and Climate Change-a comprehensive analysis. International Food Policy Research Institute, Washington DC. doi:http://dx. doi.org/10.2499/9780896292086

Haines RW, Lye KA (1983) The sedges and rushes of East Africa. East African Natural History Society, Nairobi

Hanjra MA, Qureshi ME (2010) Global water crisis and future food security in an era of climate change. Food Policy 35:365-377 Hartter J, Ryan SJ (2010) Top-down or bottom-up? Decentralization, natural resource management, and usufruct rights in the forests and wetlands of western Uganda. Land Use Policy 27:815-826

Heckman CW (1998) The Pantanal of Poconé - biota and ecology in the northern section of the world's largest pristine wetland. Kluwer Academic, Dordrecht

Howell P, Lock M, Cobb S (eds) (1988) The jonglei canal. Cambridge University Press, Cambridge

Hughes RH, Hughes JS (1992) Directory of African wetlands. IUCN, Cambridge, p 820

Iltis A, Lemoalle J (1983) The aquatic vegetation of Lake Chad. In: Carmouze JP, Durand JR, Lé vê que C (eds) Lake Chad. Dr. W. Junk Publishers, The Hague, pp 125-143

Ita EO (1994) Aquatic plants and wetland wildlife resources of Nigeria CIFA Occasional Paper 21. FAO, Rome, p 52

IUCN SSC Antelope Specialist Group (2008) Tragelaphus spekii. In: IUCN 2013. IUCN Red List of Threatened Species. Version 2013.1. http://www.iucnredlist.org/ details/22050/o. Accessed 18 Sept 2013

Johnston R, Cools J, Liersch S, Morardet S, Murgue C, Mahieu M, Zsuffa I, Uyttendaele GP (2013) WETwin: a structured approach to evaluating wetland management options in data-poor contexts. Environ Sci Policy 34:3-17

Jones MB (1987) The photosynthetic characteristics of papyrus in a tropical swamp. Oecologia 71:355-359

Jones MB, Humphries SW (2002) Impactsof the $\mathrm{C}_{4}$-sedge Cyperus papyrus $\mathrm{L}$. on carbon and water fluxes in an African wetland. Hydrobiologia 488:107-113

Jones MB, Muthuri FM (1985) The canopy structure and microclimate of papyrus (Cyperus papyrus L.) swamps. J Ecol 73:481-491

Jones MB, Muthuri FM (1997) Standing biomass and carbon distribution in a papyrus (Cyperus papyrus L.) swamp on Lake Naivasha, Kenya. J Trop Ecol 13:347-356

Jones K, Lanthier Y, van der Voet P, van Valkengoed E, Taylor D, Ferná ndez-Prieto D (2009) Monitoring and assessment of wetlands using Earth Observation: the Glob Wetland project. J Environ Manage 90:2154-2169 
Kaggwa RC, van Dam AA, Balirwa JS, Kansiime F, Denny P (2009) Increasing fish production from wetlands at Lake Victoria, Uganda using organically manured seasonal wetland fish ponds. Wetl Ecol Manage 17:257-277

Kansiime F, Nalubega M (1999) Wastewater treatment by a natural wetland: the Nakivubo Swamp, Uganda. Process and implications. PhD thesis, Agricultural University of Wageningen, Wageningen

Kansiime F, Saunders MJ, Loiselle SA (2007) Functioning and dynamics of wetland vegetation of Lake Victoria: an overview. Wetl Ecol Manage 15:443-451. doi:10.1007/ s11273-007-9043-9

Khisa PS, Uhlenbrook S, van Dam AA, Wenninger J, van Griensven A, Abira M (2013) Ecohydrological character- ization of the Nyando wetland, Lake Victoria, Kenya: a State of System (SoS) analysis. Afr J Environ Sci Tech 7:417-434

Kibwage JK, Onyango PO, Bakamwesiga H (2008) Local institutions for sustaining wetland resources and commu- nity livelihoods in the Lake Victoria basin. Afr J Environ Sci Tech 2:97-106

Kinaro ZO (2008) Wetland conversion to large-scale agricul- tural production; implications on the livelihoods of rural communities, Yala Swamp, Lake Victoria basin, Department of Water and Environmental Studies. University of Lingkö ping, Sweden

Kipkemboi J, van Dam AA, Ikiara MM, Denny P (2007) Inte- gration of smallholder wetland aquaculture-agriculture systems (Fingerponds) into riparian farming systems at the shores of Lake Victoria, Kenya: socio-economics and livelihoods. Geogr J 173:257272

Kipkemboi J, Kilonzi CM, van Dam AA, Kitaka N, Mathooko JM, Denny P (2010) Enhancing the fish production potential of Lake Victoria papyrus wetlands, Kenya, using seasonal flood-dependent ponds. Wetl Ecol Manage 18:471-483. doi:10.1007/s11273-010-9180-4

Kivaisi AK (2001) The potential for constructed wetlands for wastewater treatment and reuse in developing countries: a review. Ecol Eng 16:545-560

Kiwango YA, Wolanski E (2008) Papyrus wetlands, nutrients balance, fisheries collapse, food security, and Lake Vic- toria level decline in 2000-2006. Wetl Ecol Manage 16:89-96. doi:10.1007/s11273-007-9072-4

Kiwango YA, Moshi G, Kibasa W, Mnaya B (2013) Papryus wetlands creation, a solution to improve food security and save Lake Victoria. Wetl Ecol Manage 21:147-154

Kotze D (2010) WET-Sustainable Use, a system for assessing the sustainability of wetland use. WRC Report TT 438/o9. Wetland Health and Importance Research Programme, Water Research Commission, Gezina

Kotze D, Marneweck G, Batchelor A, Lindley D, Collins N (2008) WET-EcoServices: a technique for rapidly assess- ing ecosystem services supplied by wetlands. WRC Report TT339/o8. Water Research Commission, Pretoria

Kyambadde J, Kansiime F, Gumaelius L, Dalhammar G (2004) A comparative study of Cyperus papyrus and Miscanthi- dium violaceum-based constructed wetlands for wastewa- ter treatment in a tropical climate. Water Res 38:475-485 
Kyambadde J, Kansiime F, Dalhammar G (2005) Nitrogen and phosphorus removal in substrate-free pilot constructed wetlands with horizontal surface flow in Uganda. Water Air Soil Pollut 165:37-59. doi:10.1007/s11270-005-4643-6

Lind E, Visser S (1962) A study of a swamp at the north end of Lake Victoria. J Ecol 50:599613

Loiselle S, Có zar A, van Dam AA, Kansiime F, Kelderman P, Saunders M, Simonit S (2006) Development of tools for wetland ecosystem resource management in East Africa: focus on the Lake Victoria papyrus wetlands. In: Verho- even JTA, Beltman B, Bobbink R, Whigham DF (eds) Wetlands and natural resource management. Ecological Studies 190, Springer, New York

Loiselle SA, Azza N, Cozar A, Bracchini L, Tognazzi A, Dattilo A, Rossi C (2008) Variabillity in factors causing light attenuation in Lake Victoria. Freshw Biol 53:535-545

Maclean IMD, Hassall M, Boar RR, Lake IR (2006) Effects of disturbance and habitat loss on papyrus-dwelling passe- rines. Biol Cons 131:349-358

Magole L (2008) The feasibility of implementing an integrated management plan of the Okavango Delta, Botswana. J Phys Chem Earth Parts A/B/C 33(8-13):906-912

Magole L, Kgomotso P (2010) Evolution or illusion? The Ok- avango Delta management planning process versus the conventional planning system in the face of climate change and variability in Botswana. ICID ? 18 2nd International Conference: Climate, Sustainability and Development in Semi-arid Regions August 16-20, 2010, Fortaleza-Ceará, Brazil. http://www.dewpoint.org.uk/Asset\%2oLibrary/ICID18/13MAGOLE_et_al_ICID?18.pdf

Malerba L (1968) History of the papyrus plant in Sicily and the manufacture of paper in Syracuse 112 (in Italian)

Maltby E (ed) (2009) Functional assessment of wetlands. Towards evaluation of ecosystem services. Woodhead Publishing Limited, Oxford

Maltby E, Acreman MC (2011) Ecosystem services of wetlands: pathfinder for a new paradigm. Hydrol Sci J 56:1341-1359 Mazvimavi D, Wolski P (2006) Long-term variations of annual flows of the Okavango and Zambezi Rivers. J Phys Chem Earth Parts A/B/C 31(15-16):944-951

McCarthy TS, Ellery WN (1994) The effect of vegetation on soil and ground water chemistry and hydrology of islands in the seasonal swamps of the Okavango Fan, Botswana. J Hydrol 154:169-193

McCarthy TS, Ellery WN (1998) The Okavango Delta. Trans Royal Soc S Afr 53(2):157-182

McCartney M, Rebelo LM, Senaratna Sellamuttu S, de Silva S (2010) Wetlands, agriculture and poverty reduction. Colombo, Sri Lanka: International Water Management Institute, p 39. IWMI Research Report 137. doi:10.5337/ 2010.230

McClanahan TR, Young TP (eds) (1996) East African ecosys- tems and their conservation. Oxford University Press, Oxford

MEA (2005) Ecosystems and human well-being: wetlands and water synthesis. Millennium Ecosystem Assessment, World Resources Institute, Washington, DC

Mmopelwa G (2006) Economic and financial analysis of har- vesting and utilization of river reed in the Okavango Delta, Botswana. J Environ Manage 79:329-335 
Mnaya B, Wolanski E (2002) Water circulation and fish larvae recruitment in papyrus wetlands, Rubondo Island, Lake Victoria. Wetl Ecol Manage 10:133-143

Mnaya B, Wolanski E, Kiwango Y (2006) Papyrus wetlands a lunar-modulated refuge for aquatic fauna. Wetl Ecol Manage 14:359-363

Mnaya B, Asaeda T, Kiwango Y, Ayubu E (2007) Primary production in papyrus (Cyperus papyrus L.) of Rubondo Island, Lake Victoria, Tanzania. Wetl Ecol Manage 15:269-275

Mohamed YA, Bastiaanssen WGM, Savenije HHG (2004) Spatial variability of evaporation and moisture storage in the swamps of the upper Nile studied by remote sensing techniques. J Hydrol 289:145-164

Morrison EHJ, Upton C, Odhiambo-K'oyooh K, Harper DM (2012) Managing the natural capital of papyrus within riparian zones of Lake Victoria, Kenya. Hydrobiologia 692:5-17. doi:10.1007/s10750-011-0839-5

Moyini Y, Muramira E, Emerton L, Shechambo F (2002) The costs of environmental degradation and loss to Uganda's economy with particular reference to poverty eradication. IUCN-The World Conservation Union, Eastern Africa Regional Office, Nairobi, p 8

Muccigrosso JD (2013) Papyrology homepage. http://www.users. drew.edu/*jmuccigr/papyrology. Accessed 7 Sept 2013

Murray-Hudson M, Wolski P, Ringrose S (2006) Scenarios of the impact of local and upstream changes in climate and water use on hydro-ecology in the Okavango Delta, Bots- wana. J Hydrol 331:73-84

Mwakubo SM, Obare GA (2009) Vulnerability, livelihood assets and institutional dynamics in the management of wetlands in Lake Victoria watershed basin. Wetl Ecol Manage 17:613-626

Mwanuzi F, Aalderink H, Mdamo L (2003) Simulation of pol- lution buffering capacity of wetlands fringing the Lake Victoria. Environ Int 29:95-103

Namaalwa S, van Dam AA, Funk A, Ajie GS, Kaggwa RC (2013) A characterization of the drivers, pressures, eco- system functions and services of Namatala wetland, Uganda. Environ Sci Policy 34:44-57. doi:10.1016/j. envsci.2013.01.002

Ojoyi MM (2006) Sustainable use of papyrus (Cyperus papyrus) at Lake Victoria wetlands in Kenya: a case study of Dunga and Kusa swamps. Monterrey Institute of Technology and Higher Education, Mexico

Okurut TO (2001) Plant growth and nutrient uptake in a tropical constructed wetland. In: Vymazal $J$ (ed) Transformations of nutrients in natural and constructed wetlands. Backhuys, Leiden, pp 451-462

Okurut TO, Rijs GBJ, van Bruggen JJA (1999) Design and performance of experimental constructed wetlands in Uganda, planted with Cyperus papyrus and Phragmites mauritianus. Water Sci Tech 40:265-271

Ostrovskaya E, Douven W, Schwartz K, Pataki B, Mukuyu P, Kaggwa RC (2013) Capacity for sustainable management of wetlands: Lessons from the WETwin project. Environ Sci Policy 34:128-137. doi:10.1016/j.envsci.2012.08.006

Osumba JJL, Okeyo-Owuor JB, Raburu PO (2010) Effect of harvesting on temporal papyrus (Cyperus papyrus) bio- mass regeneration potential among swamps in Winam Gulf wetlands of Lake Victoria Basin, Kenya. Wetl Ecol Man- age 18:333-341 
Ouedraogo P (2013) Regional overview of the implementation of the Convention and its Strategic Plan in Africa. 11th Conference of the Parties to the Ramsar Convention on Wetlands, Bucharest, Romania 6-13 July 2012, Information Document COP11DOC.9. http://www.ramsar.org/

Owino AO, Ryan PG (2007) Recent papyrus swamp habitat loss and conservation implications in western Kenya. Wetl Ecol Manage 15:1-12

Ozesmi SL, Bauer ME (2002) Satellite remote sensing of wet- lands. Wetl Ecol Manage 10:381-402

Peh KSH, Balmford A, Bradbury RB, Brown C, Butchart SH, Hughes FM, Stattersfield A, Thomas DHL, Walpole M, Bayliss J, Gowing D, Jones JPG, Lewis SL, Mulligan M, Pandeya B, Stratford C, Thompson JR, Turner K, Vira B, Willcock S, Birch JC (2013) TESSA: a toolkit for rapid assessment of ecosystem services at sites of biodiversity conservation importance. Ecosyst Serv 5:51-57

Pretty J (1999) Can sustainable agriculture feed Africa? New evidence on progress, process and impacts. Environ Dev Sust 1:253-274

Ramsar (2013) The list of wetlands of international importance (24 October 2013). http://www.ramsar.org

Raynal-Roques A (1980) Les plantes aquatiques (Plantes a fleurs et Fougè res). In: Durand JR, Lé vêque C (eds) Flore et faune aquatiques de l'Afrique Sahelo-Soudanienne, Tome 1. É ditions de l'Office de la Recherche Scientifique et Technique Outre-Mer, Collection Initiations-Documen- tations Techniques No. 44. ORSTOM, Paris

Rebelo LM, McCartney MP, Finlayson CM (2010) Wetlands of sub-saharan Africa: distribution and contribution of agri- culture to livelihoods. Wetl Ecol Manage 18:557-572

Rodr'iguez JP, Beard Jr TD, Bennett EM, Cumming GS, Cork S, Agard J, Dobson AP, Peterson GD (2006) Trade-offs across space, time, and ecosystem services. Ecol Soc 11:28. http:// www.ecologyandsociety.org/vol11/iss1/art28/

Rongoei PJ, Kipkemboi J, Okeyo-Owuor JB, van Dam AA (2013) Ecosystem services and drivers of change in Ny- ando floodplain wetland, Kenya. Afr J Environ Sci Tech 7:274-291

Rousseau DPL, Vanrolleghem PA, De Pauw N (2004) Model- based design of horizontal subsurface flow constructed treatment wetlands: a review. Water Res 38:1484-1493

Russi D, ten Brink P, Farmer A, Badura T, Coates D, Fö rster J, Kumar R, Davidson N (2013) The economics of ecosystems and biodiversity for water and wetlands. IEEP, London

Rzoska J (1974) The upper Nile swamps, a tropical wetland study. Freshwat Biol 4:1-30

Rzoska J (Ed) (1976) The Nile. Biology of an ancient river. W. Junk Publishers, The Hague, $417 \mathrm{p}$

Saunders MJ, Jones MB, Kansiime F (2007) Carbon and water cycles in tropical papyrus wetlands. Wetl Ecol Manage 15:489-498

Savenije HHG (1995a) Does moisture feedback affect rainfall significantly? Phys Chem Earth 20:507-513

Savenije HHG (1995b) New definitions for moisture recycling and the relationship with land-use changes in the Sahel. J Hydrol 167:57-78 
Seid TW (2013) Interpreting ancient manuscripts web. http:// legacy.earlham.edu/*'seidti/iam/home.html. Accessed 7 Sept 2013

Serag MS (2003) Ecology and biomass production of Cyperus papyrus L. on the Nile bank at Damietta, Egypt. J Med Ecol 4:15-24

Shepherd WH (2008) The preservation and conservation of papyri. MLIS 7710 Archival Theory and Issues. http://www.yumpu.com/en/document/view/11403310/preservation-andconservation-of-papyri-comcastnet

Simonit S, Perrings C (2011) Sustainability and the value of the 'regulating' services: wetlands and water quality in Lake Victoria. Ecol Econ 70:1189-1199

Smith MR (1973) The return of papyrus. Saudi Aramco World, July/August 1973, pp 32-36. http://www.saudiaramcoworld.com/issue/197304/the.return.of.papyrus.htm. Accessed 17 Sept 2013

Tä ckholm V (1976) Ancient Egypt, landscape, flora and agri- culture. In: Rzó ska J (ed) The Nile, biology of an ancient river. Dr. W. Junk B.V, The Hague, pp 51-68

Talling JF (1957) The longitudinal succession of water char- acteristics in the White Nile. Hydrobiologia 11:73-89

TEEB (2010) The economics of ecosystems and biodiversity: mainstreaming the economics of nature: a synthesis of the approach, conclusions and recommendations of TEEB. United Nations Environment Program, Nairobi. http:// www.teebweb.org/

Thenya T, Wassmann R, Verchot L, Mungai D, Odada EO, Olago DO, Ochola W, Ntiba M, Wandiga S, Gichuki N, Oyieke H (2006) Degradation of the riparian wetlands in the Lake Victoria basin-Yala swamp case study. Proc 11th World Lakes Conf 2:483-494 Thompson K (1976) Swamp development in the headwaters of the White Nile. In: Rzoska J (ed), The Nile, biology of an ancient river. Dr. W. Junk, The Hague, Monogr Biol 29:177-196

Thompson K (1985) Emergent plant of permanent and season- ally flooded wetlands. In: Denny P (ed) The Ecology and Management of African Wetland Vegetation. Dr. W. Junk, Dordrecht, pp 43-107

Thompson K, Hamilton AC (1983) Peatlands and swamps of the African continent. In: Gore AJP (ed) Mires: swamp, bog, fen and moor. Elsevier Ecosystems of the World 4:331373

Thompson K, Shewry PR, Woolhouse HW (1979) Papyrus swamp development in the Upemba Basin, Zaire: studies of population structure in Cyperus papyrus stands. Biol $\mathrm{J}$ Linn Soc 78:299-316

Tristram HB (1866) Note on the existence of the true Cyperus papyrus L., Palestine. J Linn Soc Lond Bot 9(8):329-330 Tristram HB (1883) The natural history of the Bible, being a review of the physical geography, geology and meteorology of the Holy Land. Society for Promoting Christian Knowledge, London. Wellesley Internet Archive, http:// archive.org/details/naturalhistoryofootris

UNECA (2013) Making the most of Africa's commodities: industrializing for growth, jobs and economic transfor- mation. Economic Report on Africa, United Nations Economic Commission for Africa, Addis Ababa, Ethiopia. http:// www.uneca.org/publications/economic-report-africa-2013 
van Dam AA, Kipkemboi J, Zaal AM, Okeyo-Owuor JB (2011) The ecology of livelihoods in East African papyrus wetlands (ECOLIVE). Rev Environ Sci Biotech 10:291-300

van Dam AA, Kipkemboi J, Rahman MM, Gettel GM (2013) Linking hydrology, ecosystem function, and livelihood outcomes in African papyrus wetlands using a Bayesian Network model. Wetlands 33:381-397. doi:10.1007/s13157-013-0395-Z

Whigham DF, Dykyjová D, Hejný S (eds) (1993) Wetlands of the World I. Kluwer Academic, Dordrecht

WID/IUCN (2005) From conversion to conservation: fifteen years of managing wetlands for people and the environment in Uganda. Wetlands Inspection Division, Uganda; and IUCN, Eastern Africa Regional Programme, Nairobi, 92

$\mathrm{WMD} / \mathrm{NU}$ (2008) Implementing the Ramsar convention in Uganda-a guide to the management of Ramsar sites in Uganda. Wetland Management Department, Ministry of Water and Environment and and Nature Uganda, Kampala

Wood A, van Halsema GE (2008) Scoping agriculture-wetland interactions. Towards a sustainable multiple-response strategy. FAO Water Report 33. Food and Agriculture Organization of the United Nations, Rome

Wood A, Dixon A, McCartney M (eds) (2013) Wetland man- agement and sustainable livelihoods in Africa. Routledge, London/New York 